\title{
Indication of the state of peatland ecosystems in Bosnia and Herzegovina
}

\section{Indikacija stanja ekosistema tresetišta u Bosni i Hercegovini}

\author{
Senka Barudanovićl,*, Ermin Mašićl, Armin Macanović1, Ena Hatibović
}

University of Sarajevo, Faculty of Science, Zmaja od Bosne 33-35, Sarajevo, Bosnia and Herzegovina

\begin{abstract}
Peatland ecosystems in Bosnia and Herzegovina represent a relict remain of the vegetation, flora and fauna from the glaciation periods. Peatlands are widespread on the North, where they occupy large areas of northern Europe, Asia and Canada. Occurrence of this type of ecosystems in Bosnia and Herzegovina contains an indication of nature conservation in general and represents an extraordinary natural value. The status of peatland ecosystems in the Balkans should be carefully monitored especially today, at the time of the already recognizable effects of climate change. The preserved structure and functionality of these ecosystems might indicate satisfactory degree of resilience to climate change, but adverse state warns on the need to take appropriate actions. Multiply drivers as overexploitation of natural resources, water, air and soil pollution and spread of invasive alien species, also have a negative effect on peatland ecosystems. In order to assess the conditions of peatland ecosystems in Bosnia and Herzegovina, researches were carried out on Vranica and Zvijezda mountain in central Bosnia. Researches was conducted including the following communities: Sphagno-Piceetum montanum Stef 1964, Sphagnetum recurvo-subsecundi Grgić et al. 1991, Menyanthi-Sphagnetum Grgić et al. 1991 Scirpetum silvatici Ht et $\mathrm{H}$-ić, Calthaetum rostratae Lakušić et al. 199I, Abieti-Piceetum illyricum Fuk. 1960 Stef. 62 s.l ect. To investigate existing conditions state of the peatland ecosystems, floristic elements and life forms were determined for every plant species. A comparison of previous and today's state of these communities was conducted, associated with analysis of Ellenberg's indices for temperature, light, soil reaction etc. According to Lakušić et al., 1991., these type of ecosystems in Bosnia and Herzegovina was satisfactory. However, today's finding shows severe changes. The loss of peatland habitats was recorded in the entire area of research. The main identified drivers are deforestation, habitat conversion and drainage of watercourses. In order to protect this type of ecosystems and important indicator species it is necessary to implement different conservation and restoration activities.
\end{abstract}

Key words: peatland ecosystems, degradation, biodiversity, conservation, restoration, pressures.

Corresponding author: Senka Barudanović, Faculty of Science University of Sarajevo; Zmaja od Bosne 33-35, 7I000 Sarajevo, Bosnia and Herzegovina; e-mail address: sebarudanovic@gmail.com 


\section{INTRODUCTION - Uvod}

Peatland ecosystems represent a specific type of vegetation that at the global level makes up only $3 \%$ of the earth's surface (Houghton et al. 1990), and whose significance is particularly emphasized in the carbon cycle processes (Gorham, 1991, 1995; Roulet, 2000). This role is even greater today, which is especially important in the period of intense climate change due to the capability of carbon retention and storage (Houghton et al., 1990). Peatlands increasingly play a role in policy relating to climate change, biodiversity and ecosystem services (Tanneberger et al., 2017). Besides the important role in the key processes of the geobiosphere, these ecosystems also represent very important habitats of many plant species of specific life forms. In accordance with environmental conditions they developed a set of morphological, anatomical, physiological and phenological characteristics that represent the type of organization of the species and their adaptive behavior. The belonging to a certain life form is also reflected in a specific habitus, the use of certain resources and the speed of physiological processes, etc. (Stevanović \& Janković, 200I). Particular role in peatlands have species of the genus Sphagnum which, thanks to their morphological and physiological properties, imitate sponges. They retain a large amount of water in their inter- and intracellular spaces (Rydin \& Jeglum, 20I3; Rice et al., 2008) which is a special characteristic of these ecosystems. To the specificity of peatlands also contribute other types of mosses and sedges, whose productivity varies. In bogs where the main species are mosses, there is a lower intensity of photosynthesis compared to fens. However, sedge develop later, so the duration of photosynthesis intensity is much longer in bogs with mosses (Glenn et al., 2006). Beside specific plant and animal species, peatlands are unique in their formation processes. It is considered that they were mostly formed by processes of paludification (7I\%) and terestrialization (28\%) (Wider \& Vitt, 2006).

Peatland ecosystems in Bosnia and Herzegovina occupy small areas and make specific habitats for many indigenous species. They were researched last time 30 years ago when knowledge about them was very scarce. At that time, their structure and dynamics were examined for the first time in detail, focusing on ecological, pedological and microclimatic factors and the composition of flora and fauna (Lakušić et al., 1991).According to the aforementioned researches, areas in which these peatland ecosystems are described are known today. They include mountain areas of Romanija (locality Han Kram), Zvijezda Mountain (locality Ponikve; Šimin Potok and 34 Bijambare), Jahorina Mountain (locality Dugo polje),
Vranica Mountain (surroundings of Prokoško Lake), Bardača (Lijevče polje), Gatačko polje, Posavina area, Rača (Bijeljina), Podrašničko polje, Gromiželj greater area of Livanjsko polje (locality Ždralovac), etc. (Lakušić et al., I991; Joosten et al., 2017).

Peatland ecosystems at the mentioned sites are formed by different processes. Those, in areas of Bijambare and Šimin Potok (Zvijezda mountain), were formed by the process of terestrialization. In terms of supply of mineral matter they belong to minerotrophic type of peatland. On the other hand, the peatlands on mountains Vranica and Zvijezda were formed by the process of paludification. They are supplied with water only from precipitation and, according to the content of nutrients, they are classified ombrotrophic type (Barudanović et al., 2017).
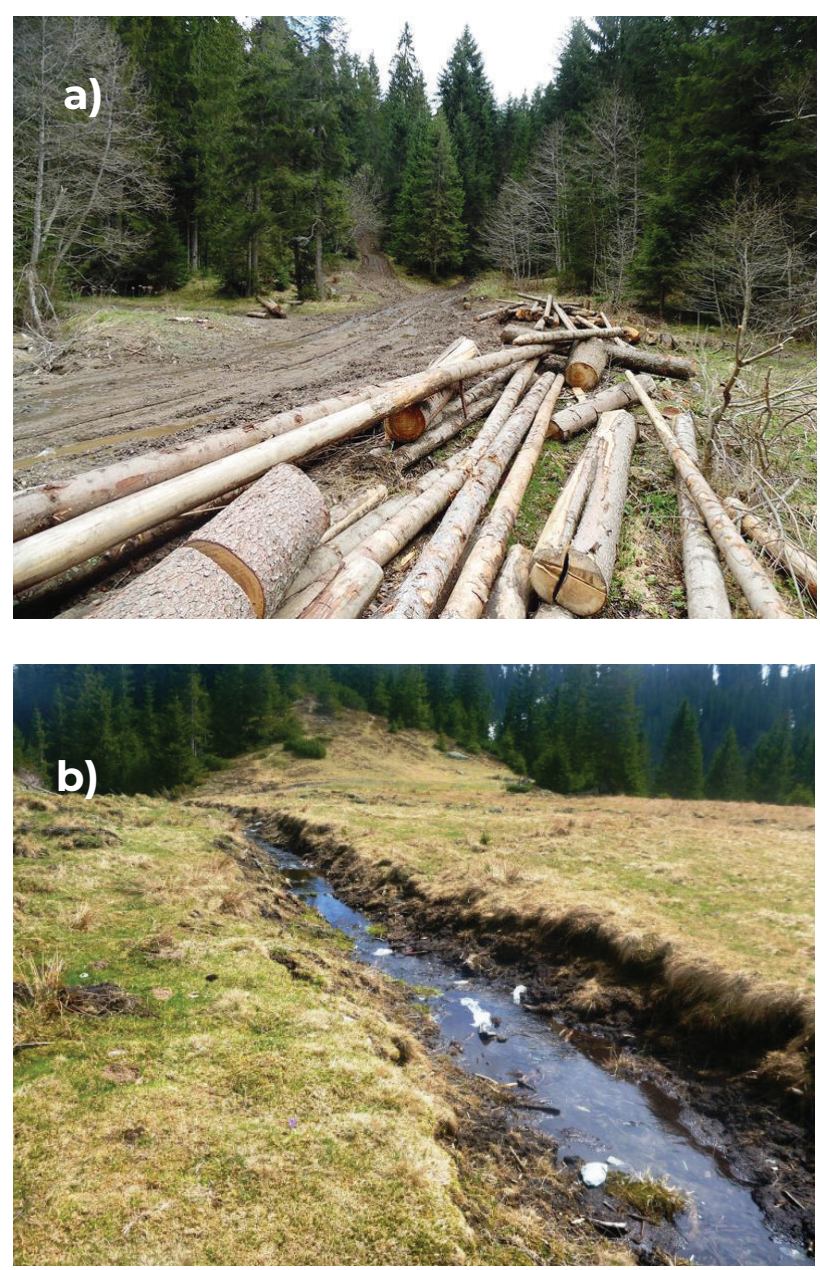

Figure I. Pressures on peatland ecosystems (a) logging on Zvijezda Mountain; (b) drainage channels on Vranica Mountain

Slika I. Pritisci na ekosisteme tresetišta (a) izvlačenje drveta na planini Zvijezdi (b) odvodni kanali na planini Vranici

The researched peatland areas represent significant centers of endemism in $\mathrm{BiH}$. The Vranica Mountain as a unique silicate massif is especially distinguished. Beside a 
large number syntaxonomic units of vegetation, in this area, according to the research of Kulijer (20I5) in the coastal belt of Prokoško Lake an endemic species was found, Sympetrum flaveolum (Linnaeus, 1758) from the order Odonata.

Peatland ecosystems are valuable ecosystems in $\mathrm{BiH}$. Their status should be continuously researched and protected through various monitoring mechanisms. Unfortunately, today they are exposed to intense pressures mostly derived from human activities such as: logging, drainage (Figure I, a-b), abstraction of water, land exploitation, illegal waste dumps, etc. Due to the more intense influence of pressures, their condition is gradually being disrupted, which was the main reason for the implementation of new researches, but in already known sites in order to determine the changes that occurred in their structure.

\section{MATERIAL AND METHODS - Materijal i metode}

The specific diversity of species identified through previous researches (Lakušić et al. 1991, Đug, 2003, Barudanović et al. 2017), was the subject of this paper.A repeated researches of peatland ecosystems were carried out in 2016 and 2017 in various aspects of the vegetation season. The surveys were conducted according to the Braun-Blanquet (1964) phytosociological method. The plant material was sampled and subsequently herbarized. Determination of mosses and Cormophyta was carried out using relevant literature (Pavletić, 1968; Javorka \& Csapody, 1979; Daniels \& Eddy, 1990; Domac, 2002; Atherton, Bosanquet \& Lawley, 2010). Synthetic tables were prepared according to localities, separately for each research period (1985-1986 (I), 2002 (IIA) and 2016 (II)) and established associations. Plant species are associated with life forms, floristic elements, and spectra of associations were prepared (Oberdorfer, 1979; Landolt et al., 2010). Then, a comparison of life forms and floristic elements of the plant composition was made between separate periods and association in order to determine changes in their structure. The results of the analyzes are presented in tables and in graphic. This approach sought to establish the existence of phytosociological and ecological changes at selected localities of peatland ecosystems in the past 30 years.

\section{RESULTS AND DISCUSSION - Rezultati i diskusija}

In the area of the Bosnian mountains habitats with peatland ecosystems are today still preserved. Their structure and floristic composition largely depend on the biotic and abiotic component, but also on the hydrological network. The research that was carried out included seven already known peat associations, located in the greater area of Zvijezda and Vranica mountains.
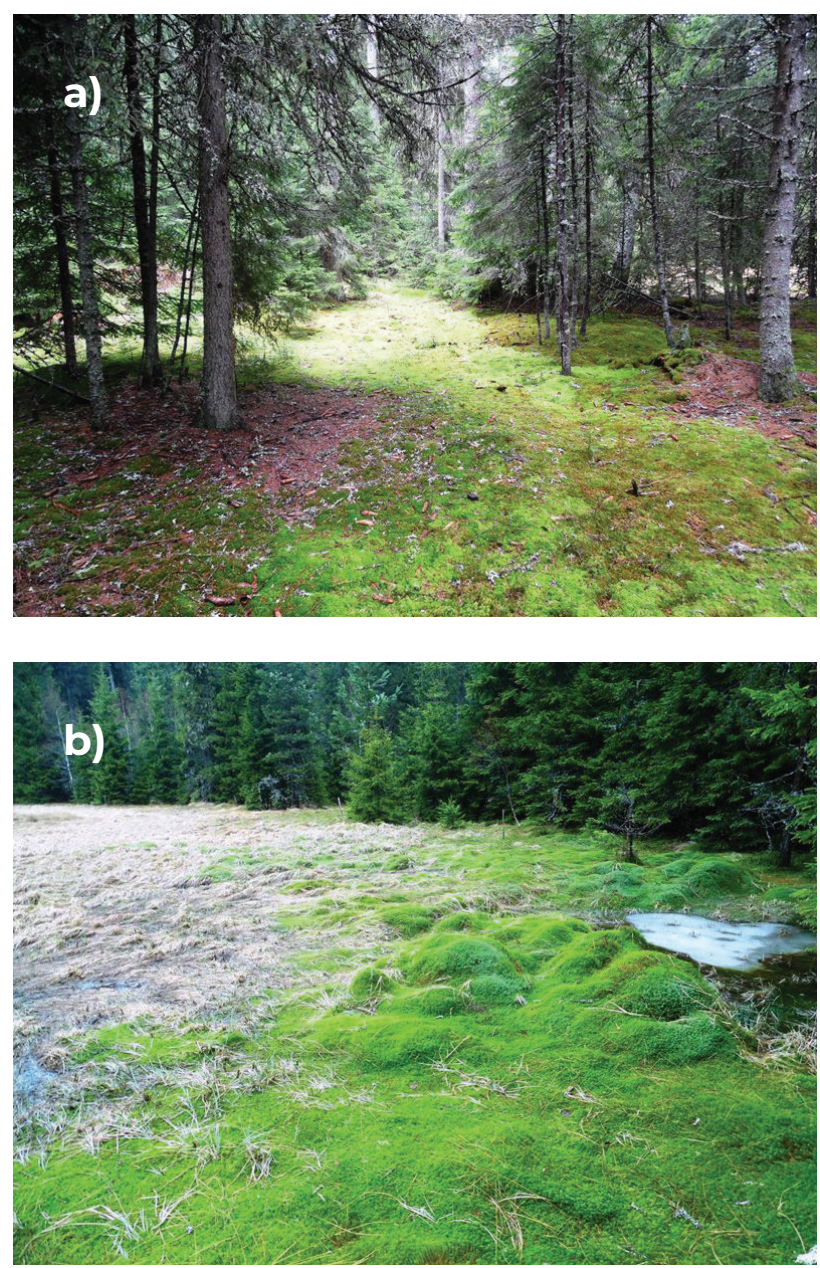

Figure 2. Researched plant communities: (a) Sphagnetum recurvo-subsecundi Grgić et al., I 99I; locality: Bijambare; b) Sphagno-Piceetum montanum Stef. 1964 locality: Bijambare;

Slika 2. Istraživane biljne zajednice: a) Sphagnetum recurvosubsecundi Grgić et al., 199I; lokalitet: Bijambare; b) SphagnoPiceetum montanum Stef. 1964 lokalitet: Bijambare

In the vicinity Zvijezda Mountain, at Bijambare locality, peatlands are surrounded by primary climatogenous forest phytocoenoses in which, according to the spatial and ecological distance from the bogs, plant species can be found with their optimum in associations of mires. The following associations have been described:Sphagnetum recurvo-subsecundi Grgić et al. I99 | (Figure Ia) and Sphagno-Piceetum montanum Stef. 1964. The community Sphagno-Piceetum montanum Stef. 1964 is particularly preserved (Figure Ib). It develops in the phytocoenosis of spruce forests at a height of 930 m.a.s.l., on ravine terrains above silicates, or on distric cambisol alternated with luvisol. The gen- 
eral coverage is about $100 \%$. The species that have the dominant role in the arboreal and shrub layer is Picea abies, and sporadically Abies alba. The most important differential species are: Luzula pilosa, Potentilla erecta, Carex canescens, $C$. echinata, Juncus effusus, Lysimachia nummularia, Ranunculus ophioglossifolius and Agrostis stolonifera. Among short shrubs are present populations of the following species: Vaccinium myrtillus, Betula pubescens, Picea abies and Salix cinerea.

According to the latest research, the floristic composition is as follows: Agrostis capillaris, Ajuga reptans, Anemone nemorosa, Angelica sylvestris, Arabis hirsuta, Aremonia agrimonoides, Asarum europaeum, Athyrium filix-femina, Blysmus compressus, Callitriche palustris, Caltha palustris, Cardamine pratensis, Carex muricata, C. pallescens, C. pendula, C. rostrata, C. sylvatica, Marchantia polymorpha etc. The differential species in the moss layer are Rhitidiadelphus squarosus, Plagiomnium affine, Dicranum scoparium, Eurhynchium striatum, Sphagnum girgensohnii, S. palustre, S. robustum etc.

Beside Bijambare, in the greater area of Zvijezda Mountain the peatlands are represented by associations: Abieti-Piceetum illyricum Fuk. 1960 em. Stef. 62 lycopodietosum annotini prov., Calthaetum rostratae Lakušić et al. 1991, Menyanthi-Sphagnetum Lakušić et al. 1991., Scirpetum sylvatici $\mathrm{Ht}$ et $\mathrm{H}$-ić prov. (in $\mathrm{Ht}$ et al. 1974). The geological substrate is made of marl and sandstone, and the soil is marshy gley.

On the locality Ponikve the association Abieti-Piceetum illyricum Fuk. 1960 em. Stef. 1962 s. I. is present. It develops at altitudes of $1060 \mathrm{~m}$ and slopes inclined 10 $20^{\circ}$. The general coverage reaches $100 \%$, and the dominant species in the layer of tall trees are: Picea abies, Abies alba and Fagus sylvatica. The moss and lichens layer is made by: Sphagnum squarrosum, S. girgensohnii, S. subsecundum, Dicranum scoparium, Brachythecium rivulare, Ptychostomum capillare, Atrichum undulatum, Plagiochila asplenioides, Eurhynchium striatum, Fegatella conica, Metzgeria conjugata etc.Although further work needs to be done on the syntaxonomic status of this community, current research on the spectrum of life forms shows some differences in the distribution of individual groups. The largest number of plant species belongs to the group of hemicriptophytes, followed by phanaerophytes and geophytes.

The association Calthaetum rostratae Lakušić et al. 1991 is present at the same locality and it develops in wet habitats along mountain sources and streams. The physiognomy of the association is determined by Caltha palustris and few differential species such as: Ve-
Carex brizoides, Leersia sp., Poa palustris and Montia palustris. The moss layer is made by: Sphagnum girgensohnii, S. palustre, S. recurvum, Brachythecium rivulare, Ptychostomum capillare, Dicranum scoparium, Eurhynchium striatum and others.
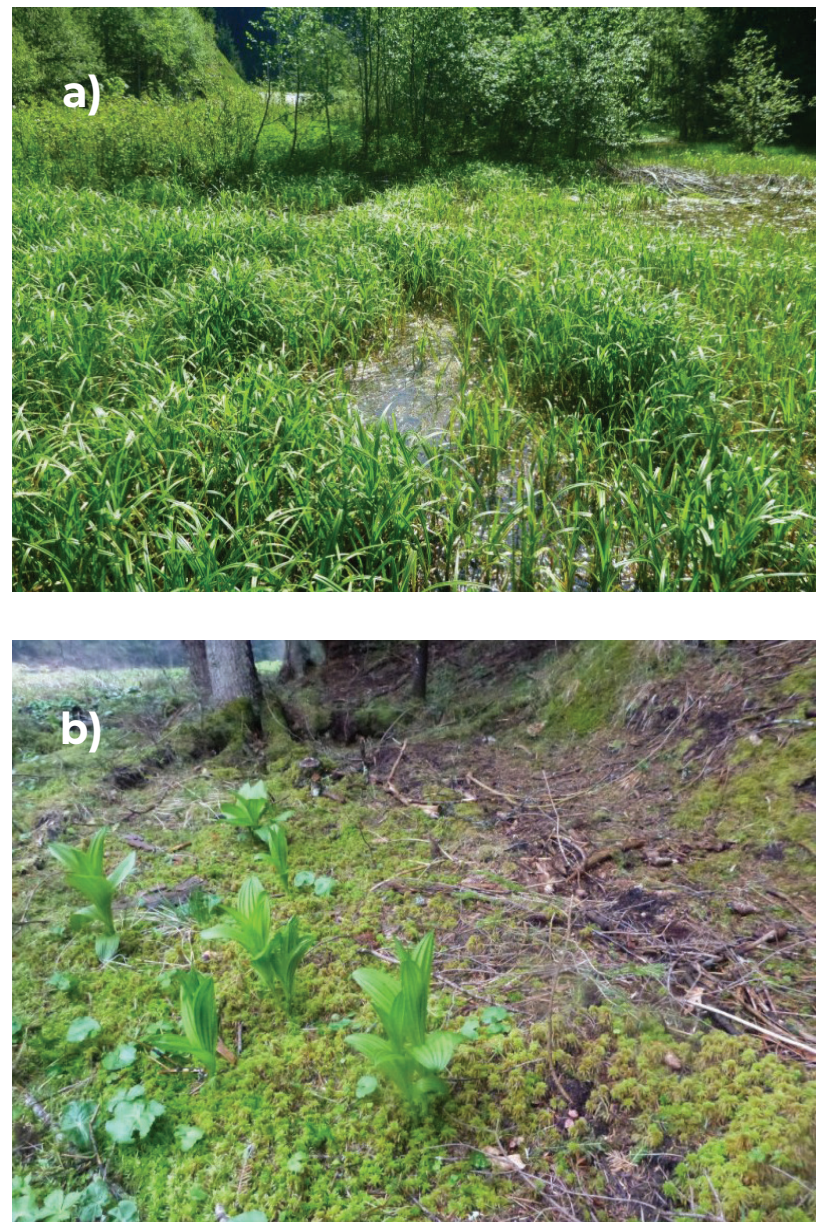

Figure 3. Researched plant communities: (a) Scirpetum sylvatici $\mathrm{Ht}$. et $\mathrm{Hi}$-ič (in $\mathrm{Ht}$ et al 1974); (b) habitat of the species Sphagnum squarrosum

Slika 3. Istraživane biljne zajednice: (a) Scirpetum sylvatici $\mathrm{Ht}$. et $\mathrm{Hi}$-ič (in $\mathrm{Ht}$ et al 1974); (b) stanište vrste Sphagnum squarrosum

The association Scirpetum sylvatici $\mathbf{H t}$ et $\mathbf{H}$-ić in $\mathbf{H t}$ et al. 1974 on Zvijezda Mountain, develops at the locality of Ponikve at a higher altitude of I,050 m. Its characteristic is that it occurs next to calm waters and on flat terrain (Figure 3, a). The physiognomy of the association is determined by: Scirpus sylvaticus, followed by Eleocharis palustris, Alisma plantago-aquatica, Carex canescens and Juncus lampocarpus. Other significant species are: Myosotis palustris, Calliergon stramineum, Rhizomnium punctatum, Galium palustre, Ranunculus repens etc. The moss layer is made by: Brachythecium rivulare, Calliergon stramineum, Plagiomnium elatum, Plagiochila asplenioides and Polytrichum commune. 
The association Menyanthi-Sphagnetum Grgić et al. 199 I at an altitude of $1050 \mathrm{~m}$, on a flat and slightly inclined slope. Phytosociological analyzes showed the highest number and coverage of species of the genus Sphagnum L. such as: Sphagnum recurvum, S. palustre, while S. subsecundum, S. squarrosum (Figure 3, b), S. quinquefarilum and $S$. girgensohnii are less represented. Among other plant species the following are present: Angelica sylvestris, Caltha palustris, Carex muricata, C. flava, Cirsium palustre, Crepis paludosa, Dactylorhiza maculata subsp. transsilvanica, Deschampsia cespitosa, Epilobium palustre, Eriophorum latifolium, Festuca rubra, Filipendula ulmaria. The moss layer is made by: Bryum capillare, Calliergonella cuspidata, Drepanocladus sp., Rhizomnium punctatum, Polytrichum commune, Scapania irrigua, Thuidium tamariscinum etc. The largest number of plant species belongs to the group of hemicriptophytes $(H)$.

According to previous researches, on Vranica Mountain there is a high degree of diversity of peatland ecosystems. Associations like: Sphagno-Piceetum montanum Stef. 1964, Sphagnum russowii-Pinus mugo prov., Saxifrago-Sphagnetum Đug 2003 prov. and Eriophoro-Pinguiculetum Đug 2003 prov. have special status. Associations develop on limestone and silicate (metariolites and riolites) (Đug, 2003). The floristic cover develops according to the specific habitat conditions where species adapted to conditions of increased humidity and low air temperatures are present. Those species are: Sphagnum russowii Warnst., Sphagnum subsecundum Nees, Ctenidium molluscum (Hedw.) Mitt., Climacium dendroides (Hedw.) F.Weber \& D. Mohr, Plagiomnium affine (Blandow ex Funck) T.J. Kop., Empetrum nigrum subsp. hermaphroditum (Hagerup) Böcher etc.

The association that develops along streams and springs is Sphagno-Piceetum montanum Stef. 1964. In the shrub layer present are Picea abies and Abies alba. The herbaceous layer is made by: Agrostis rupestris, Alchemilla xanthochlora, Angelica sylvestris, Carex leporina, C. pilulifera, Crocus imperati, Galium palustre, Luzula maxima, L. pilosa, Mentha aquatica, Oxalis acetosella, Parnassia palustris etc. In this vegetation type the following mosses are present: Climacium dendroides, Marchantia polymorpha, Pseudotaxiphyllum elegans, Rhizomnium punctatum, Sphagnum subsecundum and Cladonia pyxidata.

The association Sphagnum russowii-Pinus mugo prov. develops at an altitude of $1660-2100 \mathrm{~m}$ on different exposures. The geological substrate is mostly made of limestone, sometimes silicates, and soil type is calcomelanosol and ranker respectivelly. The characteristic species are: Pinus mugo, Calamagrostis villosa, Asarum europeum, Polygonatum verticillatum, Myosotis sylvatica and Geranium sylvaticum. A peculiarity of the association is re- flected in the presence of the species Sphagnum russowii which occurs in the habitat of Picea abies. According to new research, the composition of the vegetation of this association has not changed significantly. The species with the highest number and coverage are: Pinus mugo, Juniperus communis, Rosa pendulina, Rhododendron hirsutum, Agrostis rupestris, Alchemilla hybrida, Carex leporina, $C$. palescens, Cerastium arvense, Eriophorum latifolium, Homogyne alpina, Nardus stricta, Ranunculus platanifolius etc.
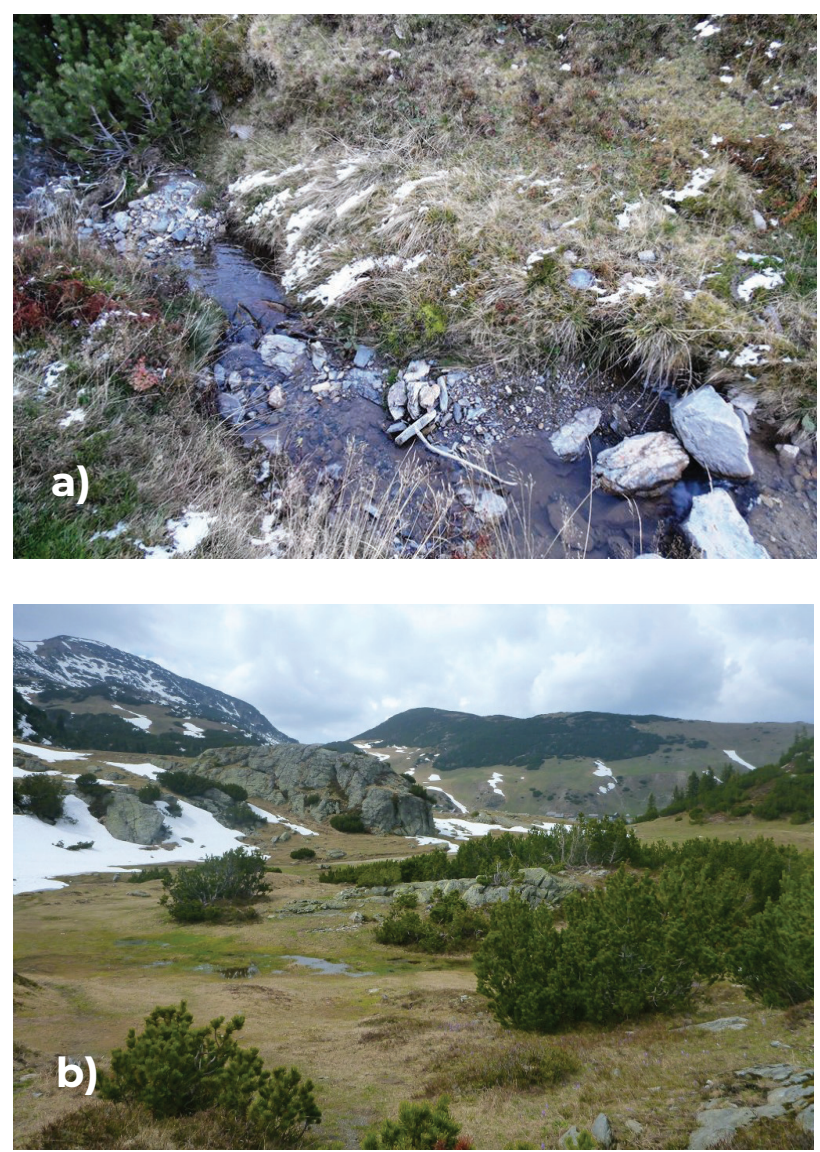

Figure 4. Researched plant communities: (a) Shagno-Piceetum montanum; (b) Sphagnum rusowii mugo prov.

Slika 3. Istraživane biljne zajednice: (a) Shagno-Piceeetum montanum; (b) Sphagnum rusowii mugo prov.

Analysis of the spectrum of life forms and floristic elements in two separate periods clearly indicates the presence of plant elements adapted to the specific conditions of the subalpine belt. The largest number of plant species belongs to the life form of hemicriptophytes $(\mathrm{H})$. Plants of this form have permanent parts that survive in the layer close to the soil. They are usually covered with leaves which protects from low temperatures, snow and ice. Those species are: Eriophorum latifolium Hoppe, Luzula campestris (L.) DC., Pinguicula leptoceras Rchb., Potentilla crantzii (Crantz) Beck ex Fritsch etc. The spectrum of floristic elements shows the dominance of species of Eurasian distribution, but 
there is a high proportion of species with Alpine and Subatlantic-Mediterranean distribution.

The results of the comparative analysis of life forms and floristic elements in both research periods are presented in Table I and 2, and graphs I, 2 and 3.

Spectra of life forms show that the biggest changes occurred in the group of hemicriptophytes. So, for example, a significant increase in the proportion of hemicriptophytes in associations was recoreded Sphagno-Piceetum montanum (Bijambare, graph I) and Abieti-Piceetum illyricum (Zvijezda, graph 3). In the association Sphagnetum recurvo-subsecundi (Bijambare) a lower proportion of hemicriptophytes in recent studies was recorded. Here, the question arises whether the observed increase in hemicriptophytes indicates a changed water regime in the soil of these associations. In any case, the change in the floristic composition in favor of hemicriptophytes can lead to a smaller amount of available water for species of mosses in the researched communities.

Changes in the proportion of geophytes and therophytes in the researched associations have also been observed. The share of plants of these life forms in peatland associations is generally low. However, it should be noted that in the associations Abieti-Piceetum illyricum, Sphagno-Piceetum montanum, but also in Calthaetum rostratae is observed the increase in geophytes and therophytes in the spectrum of life forms. It can be assumed that their increase points to the same situation as in the analysis of hemicriptophytes, and further research of these associations in Bosnia and Herzegovina should be done.

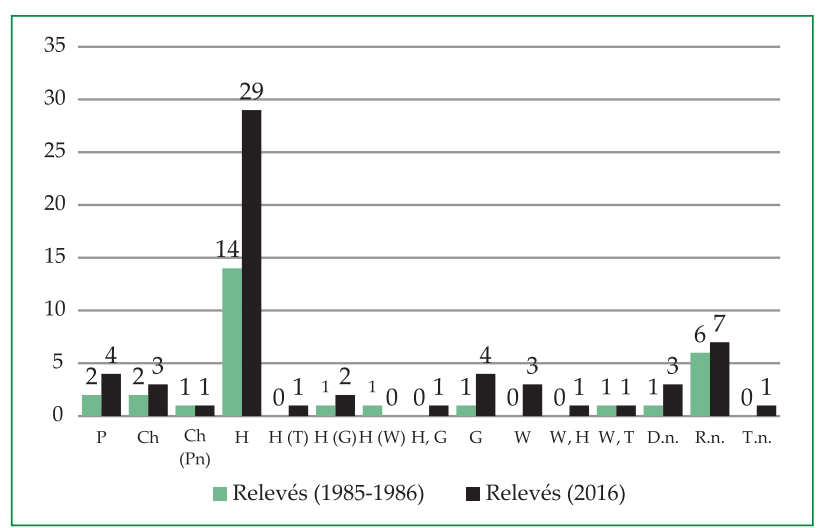

Graph I. Spectrum of life forms in Sphagno-Piceetum montanum Stef. 1964 (Bijambare) (by Raunkier, 1934; Landolt et al., 20I0) (Legend: P-Phanerophyte; Ch-Chamaephyte;

H-Hemicriptophyte; G-Geophyte, T-Therophyte; W-Water plants)

Grafikon I. Spektar živućih formi u Sphagno-Piceetum montanum Stef. 1964 (Bijambare) (by Raunkier, 1934; Landolt et al., 2010) (Legenda: P-Phanerfite; Ch-Hamefite; H-Hemikriptofite;
The analysis of the spectra of floristic elements shows the trend of the increase of the proportion of species whose areal of distribution center is in the sub-Mediterranean area. In contrast, there was also a reduction in the proportion of species originating from the Alpine, Subalpine and Northern Eurasian areas. The most obvious changes are visible in the association Sphagnetum recurvo-subsecundi in Bijambare, the best preserved peatland ecosystem in Bosnia and Herzegovina (Graph 2).

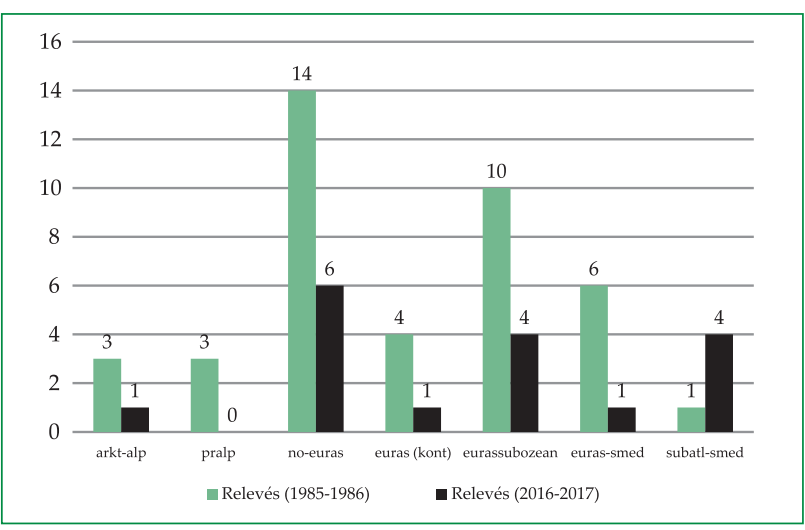

Graph 2. Spectrum of floristic elements in Sphagnetum recurvosubsecundi Grgić et al. 1991 (Bijambare) (by Oberdorfer, 1979)

Grafikon 2. Spektar flornih elemenata u Sphagnetum recurvosubsecundi Grgić et al. 1991 (Bijambare) (by Oberdorfer, 1979)

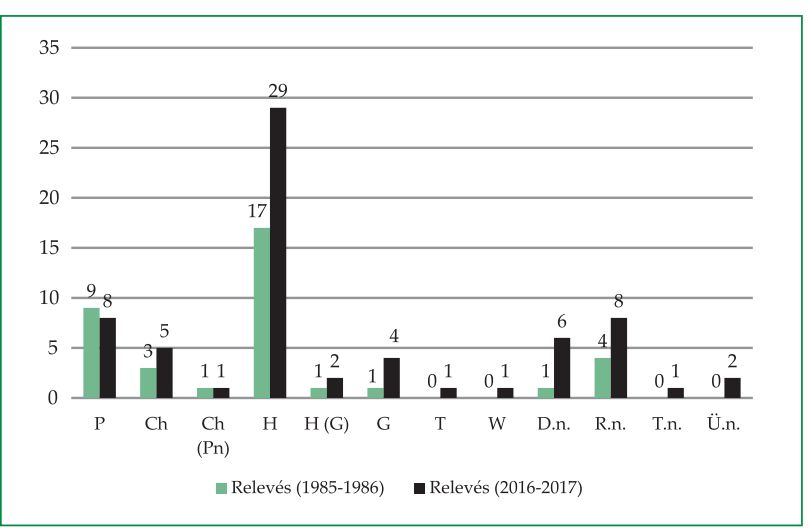

Graph 3. Spectrum of life forms in Abieti-Piceetum illyricum Fuk. 1960 em. Stef. 62 s.l (Zvijezda) (by Raunkier, 1934; Landolt et al., 2010) (Legend: P-Phanerophyte; Ch-Chamaephyte; H-Hemicriptophyte; G-Geophyte, T-Therophyte;W-Water plants)

Grafikon 31. Spektar živućih formi u Abieti-Piceetum illyricum Fuk. 1960 em. Stef. 62 s.l (Zvijezda) (by Raunkier, I 934; Landolt et al., 20l0) (Legenda: P-Phanerfite; Ch-Hamefite; H-Hemikriptofite; G-Geofite, T-Terofite;W-Vodene biljke) 
Table I. Spectrum of life forms of researched plant communities

Tabela I. Spektar živućih formi u istraživanim biljnim zajednicama

\begin{tabular}{|c|c|c|c|c|c|c|c|c|c|c|c|c|c|c|}
\hline \multirow{3}{*}{ 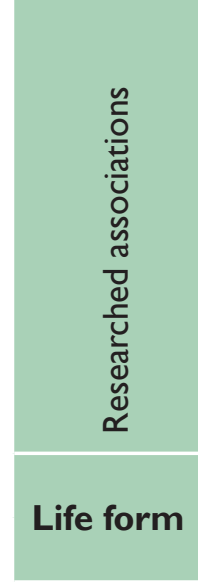 } & \multicolumn{2}{|c|}{ 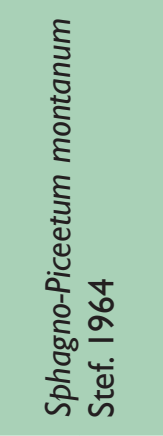 } & \multicolumn{2}{|c|}{ 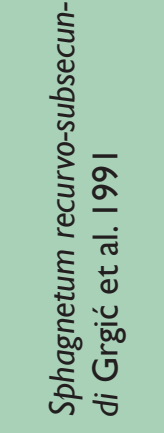 } & \multicolumn{2}{|c|}{ 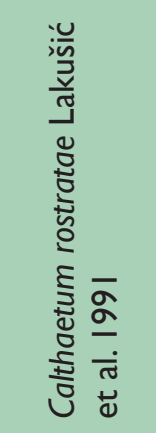 } & \multicolumn{2}{|c|}{ 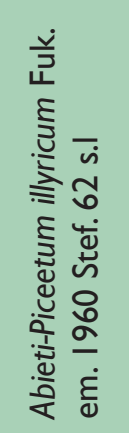 } & 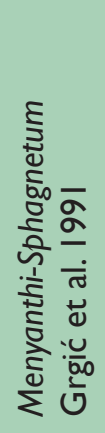 & 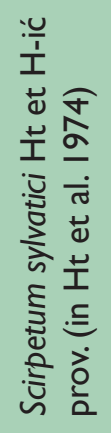 & 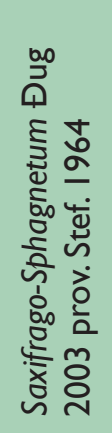 & 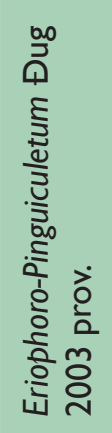 & 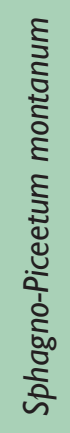 & 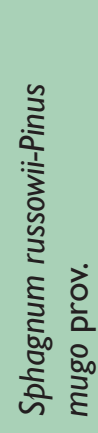 \\
\hline & \multicolumn{14}{|c|}{ RESEARCH PERIOD } \\
\hline & I & II & I & II & I & II & I & II & I & I & IIA & II & II & II \\
\hline $\mathbf{P}$ & 2 & 4 & 2 & 0 & 1 & 4 & 9 & 8 & 2 & I & 0 & I & 4 & 8 \\
\hline Ch & 2 & 3 & 2 & 1 & 2 & 3 & 3 & 5 & I & I & & & 3 & 3 \\
\hline Ch (Pn) & 1 & 1 & & & I & 1 & I & 1 & & & & & 2 & 2 \\
\hline Ch (H) & & & & & & & & & & & I & 0 & 0 & I \\
\hline $\mathbf{H}$ & 14 & 29 & 27 & 15 & 29 & 29 & 17 & 29 & 27 & 24 & 0 & 29 & 23 & 21 \\
\hline H (Ch) & & & 2 & 0 & & & & & & & 0 & 2 & 0 & 1 \\
\hline H (G) & I & 2 & & & 0 & 2 & I & 2 & & & 0 & I & I & 0 \\
\hline$H(W)$ & I & 0 & 2 & 0 & I & 1 & & & 0 & 2 & 0 & I & I & I \\
\hline H, G & 0 & 1 & & & I & 0 & & & & & & & & \\
\hline G & 1 & 4 & 1 & 0 & 1 & 4 & I & 4 & 2 & 2 & 0 & I & I & I \\
\hline G,W & & & & & & & & & & & 0 & I & & \\
\hline $\mathbf{G}(\mathbf{H})$ & & & & & 0 & 1 & & & & & & & I & 0 \\
\hline $\mathbf{T}$ & & & 1 & 0 & 0 & 1 & 0 & 1 & & & & & & \\
\hline $\mathbf{T}(\mathbf{H})$ & & & I & 0 & 1 & 0 & & & & & & & & \\
\hline W & 0 & 3 & 3 & 0 & I & 0 & 0 & 1 & I & 4 & & & & \\
\hline $\mathbf{W}(\mathrm{H})$ & & & & & I & 0 & & & & & & & & \\
\hline$W(T)$ & & & & & 0 & 1 & & & & & & & & \\
\hline W, H & 0 & 1 & & & I & 1 & & & & & 0 & I & I & I \\
\hline $\mathbf{W}, \mathbf{T}$ & 1 & 1 & & & 1 & 0 & & & & & & & & \\
\hline D.n & 1 & 3 & 1 & 3 & 1 & I & 1 & 6 & I & I & 0 & 2 & & \\
\hline R.n & 6 & 7 & 6 & 6 & 5 & 5 & 4 & 8 & 8 & I & I & 2 & 4 & 3 \\
\hline T.n & 0 & 1 & & & 1 & 1 & 0 & $I$ & & & & & I & I \\
\hline B. $n$ & & & 0 & I & & & & & & & 0 & I & 1 & I \\
\hline U.n & & & & & I & 1 & 0 & 2 & I & 1 & & & & \\
\hline
\end{tabular}


Table 2. Spectrum of floristic elements of researched plant communities

Tabela 2. Spektar flornih elemenata u istraživanim biljnim zajednicama

\begin{tabular}{|c|c|c|c|c|c|c|c|c|c|c|c|c|c|c|}
\hline \multirow[t]{3}{*}{ 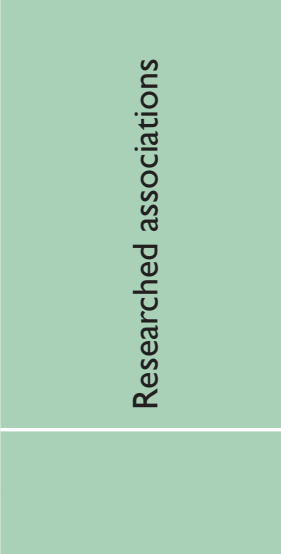 } & \multicolumn{2}{|c|}{ 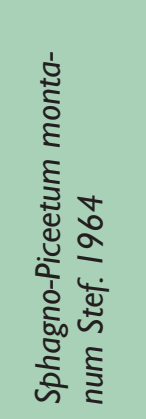 } & \multicolumn{2}{|c|}{ 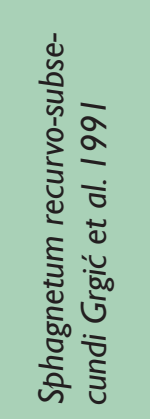 } & \multicolumn{2}{|c|}{ 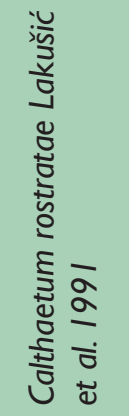 } & \multicolumn{2}{|c|}{ 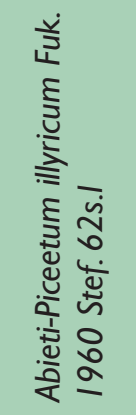 } & 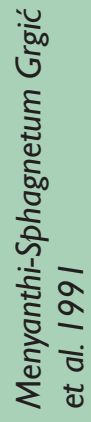 & 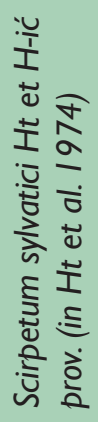 & 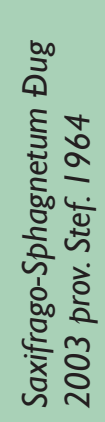 & 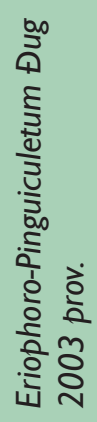 & 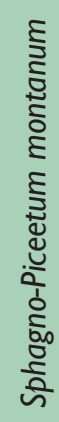 & 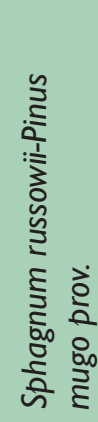 \\
\hline & \multicolumn{14}{|c|}{ RESEARCH PERIOD } \\
\hline & I & II & I & II & I & II & I & II & $\mathbf{I}$ & $\mathbf{I}$ & IIA & II & II & II \\
\hline arkt & 2 & 6 & & & 2 & 11 & 2 & 2 & & & 2 & 2 & 4 & 2 \\
\hline arkt-no & & & & & & & & & 2 & 3 & & & & \\
\hline arkt-alp & & & 3 & 1 & & & & & & & & & & \\
\hline alp & & & & & & & & & & & & & 3 & 3 \\
\hline alp-pralp & & & & & & & & & & & $\mathrm{II}$ & I & & \\
\hline pralp & I & 2 & 3 & 0 & 4 & 5 & & & 3 & 2 & & & 3 & 7 \\
\hline pralp-alp & & & & & & & 4 & 3 & & & & & & \\
\hline no-euras & 7 & 18 & 14 & 6 & 12 & II & 8 & 19 & 13 & 14 & 17 & 4 & 18 & 16 \\
\hline eurass & & & & & & & 7 & 7 & 12 & 9 & & & & \\
\hline euras-kont & 2 & 4 & & & 3 & 4 & 1 & 5 & & & & & 2 & 1 \\
\hline euras (kont) & & & 4 & 1 & & & & & & & & & & \\
\hline eurassubozean & 2 & 7 & 10 & 4 & 11 & 16 & & & & & & & 3 & 3 \\
\hline subatl & 1 & 6 & & & 4 & 3 & & & 3 & 2 & 3 & 0 & & \\
\hline subatl-smed & & & I & 4 & & & 8 & 10 & & & & & 5 & 7 \\
\hline euras-smed & 1 & 4 & 6 & 1 & & & & & & & 5 & 0 & & \\
\hline smed & I & 3 & & & 3 & 5 & 3 & 2 & I & 4 & & & & \\
\hline total & 17 & 50 & $4 I$ & 17 & 39 & 47 & 33 & 48 & 34 & 34 & 38 & 7 & 38 & 39 \\
\hline
\end{tabular}

Legend: I- research period from 1985 to 1986 year; II-research period 20I6; IIA - research period 2002

Legend:

P Phanerophyte

Ch Chamaephyte

$\boldsymbol{H}$ Hemicriptophyte

G Geophyte

$T \quad$ Therophyte
R. turf form more or less loosely growing, erect shoots; "normal" i.e. perennial without n particular strategy

D. relatively large and essentially plagiotropic shoots in deep mat; "normal" i.e. perennial n without particular strategy

B. more or less dendroid, mostly with creeping "rhizome" and erect shoots; "normal" i.e.

n perennial without particular strategy

Ü. more or less mat of small, creeping shoots; "normal" i.e. perennial without particular n strategy

T. thalloid, forming rosette or more or less branched bands; "normal" i.e. perenial without n particular strategy 


\section{CONCLUSIONS - Zaključci}

By analyzing the spectra of life forms and floristic elements in two separated periods, changes in the proportion of previously identified groups were observed.The changes in the spectra are due to changes in the floristic composition, indicating a possible change in ecological conditions in habitats of peatland associations. The increasing trend of the share of plant species with life forms of hemicriptophytes $(H)$, geophytes $(G)$ and therophytes $(T)$ is observed. It has also been observed a decreasing trend in species originating from the Alpine, Subalpine and Northern Eurasian regions, and increasing of the species with the distribution center in the sub-Mediterranean area.

\section{REFERENCES - Literatura}

Atherton, I, Bosanquet, S., \& Lawley, M. (20I0). Mosses and liverworts of Britain and Ireland - a field guide. British Bryological Society, United Kindom

Barudanović, S., Mašić, E., \& Macanović,A. (2017). Tresetišta na bosanskim planinama. Prirodno-matematički fakultet Univerziteta u Sarajevu. I- 184.

Braun-Blanquet, J. (1964). Pflanzensoziologie. Springer Verlag,Wien - New York.

Daniels, R. E. \& Eddy, A. (1990). Handbook of European Sphagna. Institute of Terrestrial Ecology, Natural Enviroment Research Council. London, HMSO, 263 Pp.

Domac, R. (2002). Flora Hrvatske - Priručnik za određivanje bilja, Il izdanje. Zagreb: Školska knjiga.

Đug, S. (2003). Diverzitet i konzervacija vegetacije subalpinskog pojasa planine Vranice. Doktorska disertacija. Prirodnomatematički fakultet, Univerziteta u Sarajevu.

Glenn,A.J., Flanagan, L. B., Syed, K. H., Carlson, P.J. (2006). Comparison of net ecosystem $\mathrm{CO} 2$ exchange in two peatlands in western Canada with contrasting dominant vegetation, Sphagnum and Carex, Agricultural and Forest Meteorology, I 40 (I-4), I I5-I35.

Gorham, E. (199I). Northern peatlands: role in the carbon cycle and probable responses to climatic warming. Ecol.Appl. I: 182-195.

Gorham, E. (1995). The biogeochemistry of northern peatlands and its possible responses to global warming. In: Woodwell, G.M. \& Mackenzie, F.T. (eds.), Biotic Feedbacks in the Global Climate System:Will the Warming Feed the Warming? pp. 169-186. Oxford University Press, Oxford, UK.
Houghton, J. T., Jenkins, G. E. J. \& Ephraums, J. J. (eds) (1990). Climate change. The IPCC scientific assessment. Cambridge Univ. Press, Cambridgge.

Javorka, S., \& Csapody, V. (1979). Ikonographie der Flora des Sudostlichen Metelleurope. Germany: Gustav Fisher Verlag.

Joosten, H.,Tanneberger, F., \& Moen,A. (eds.) (20I7). Mires and peatlands of Europe. Status, distribution and conservation. Schweizerbart Science Publishers. Stuttgart

Kulijer, D. (2015). Sympetrum flaveolum in the Dinaric Alps (Odonata: Libellulidae). Libellula 34. I/2 9I-I0I.

Lakušić, R., Grgić, P., Kutleša, Lj., Muratspahić, D., Redžić, S., Barudanović, S. (199I). Struktura i dinamika fitocenoza u ekosistemima tresetišta na planinama Bosne. Bilten Društva ekologa BiH, serija a, Ekološke monografije, No. 7, 35-84.

Landolt, E., Bäumler, B., Erhardt, A., Hegg, O., Klötzli, F., Lämmler, W., Michael Nobis, M., Rudmann-Maurer, K., Schweingruber, H.F., Theurillat, J-P., Urmi, E., Vust, M., Wohlgemuth, T. (2010). Flora indicativa. Ökologische Zeigerwerte und biologische Kennzeichen zur Flora der Schweiz und der Alpen. Ecological indicators values and biological attributes of the flora of Switzerland and the Alps (2nd ed.). Verlag Paul Haupt, Wien.

Oberdorfer, E. (1979). Pflanzensoziologische Excursions Flora.Verlag Eugen Ulmer. Stuttgart.

Pavletić, Z. (1 968). Flora mahovina Jugoslavije. Sveučilište u Zagrebu, Zagreb.

Rice, S. K., Aclander, L., \& Hanson, D. T. (2008). Do bryophyte shoot systems function lice vascular plant leaves or conopies? Functional trait relationship in Sphagnum mosses (Sphagnaceae). American Journal of Botany. 95, I366-I374.

Roulet, N.T. (2000). Peatlands, carbon storage, greenhouse gases, and the Kyoto Protocol: prospects and significance for Canada. Wetlands 20: 605-6I5.

Rydin, H. \& Jeglum, J. K. (20I3). The biology of peatlands. Second Edition. Biology of Habitats. Oxford University Press. PP I-382.

Stevanović, M. B., \& Janković, M. M. (200I). Ekologija biljaka sa osnovama fiziološke ekologije biljaka. Prvo izdanje. Beograd, 
Tanneberger, F., Tegetmeyer, C., Busse, S., Barthelmes, A., Shumka, S., Moles Mariné, A., Jenderedjian, K., Steiner, G. M., Essl, F., Etzold, J., Mendes, C., Kozulin, A., Frankard, P., Milanović, D., Ganeva, A., Apostolova, I., Alegro, A., Delipetrou, P., Navrátilová, J., Risager, M., Leivits, A., Fosaa,A. M., Tuominen, S., Muller, F., Bakuradze, T., Sommer, M., Christanis, K., Szurdoki, E., Oskarsson, H., Brink, S. H., Connolly, J., Bragazza, L., Martinelli, G., Aleksāns, O., Priede,A., Sungaila, D., Melovski, L., Belous, T., Saveljić, D., de Vries, F., Moen, A., Dembek, W., Mateus, J., Hanganu, J.,
Sirin, A., Markina, A., Napreenko, M., Lazarević, P., Šefferová Stanová, V., Skoberne, P., Heras Pérez, P., Pontevedra - Pombal, X., Lonnstad, J., Küchler, M., Wüst Galley, C., Kirca, S., Mykytiuk, O., Lindsay, R. and Joosten, $\mathrm{H}$. (2017). The peatland map of Europe. Mires and Peat. 19 (Art.22), pp. I-I7.

Wider, R.K.\&Vitt, D.H (2006). Boreal Peatland Ecosystems. Ecological Studeism, Analysis and Synthesis.Vol. 188. Springer. pp I-447

\section{SAŽETAK}

Ekosistemi tresetišta u Bosni i Hercegovini predstavljaju reliktni ostatak vegetacije, flore i faune iz perioda glacijacije. Tresetišta su raširena na sjeveru, gdje zauzimaju velika područja sjeverne Evrope, Azije i Kanade. Pojava ove vrste ekosistema u Bosni i Hercegovini sadrži naznake očuvanja prirode uopšte i predstavlja izvanrednu prirodnu vrijednost. Status ekosistema tresetišta na Balkanu treba pažljivo pratiti posebno danas, u vrijeme već prepoznatljivih efekata klimatskih promjena. Očuvana struktura i funkcionalnost ovih ekosustava mogu ukazivati na zadovoljavajući stupanj otpornosti na klimatske promjene, ali nepovoljno stanje upozorava na potrebu poduzimanja odgovarajućih radnji. Višestruki pokretači prekomjernog iskorištavanja prirodnih resursa, zagađenje vode, vazduha i tla i širenje invazivnih stranih vrsta, takođe imaju negativan efekat na ekosisteme tresetišta. $U$ cilju procjene stanja ekosistema tresetišta u Bosni i Hercegovini, vršena su istraživanja na planini Vranica i Zvijezda u srednjoj Bosni. Istraživanje je sprovedeno na sljedećim zajednicama: Sphagno-Piceetum montanum Stef 1964, Sphagnetum recurvo-subsecundi Grgić i sur. 1991, Menyanthi-Sphagnetum Grgić i dr. 1991. Scirpetum silvatici Ht i H-ić, Calthaetum rostratae Lakušić i dr. 1991, Abieti-Piceetum illyricum Fuk. 1960 Stef. 62 s.l ect. Da bi se istražilo postojeće stanje ekosistema tresetišta, utvrđeni su floristički elementi i oblici života za svaku biljnu vrstu. Provedena je usporedba prethodnog i današnjeg stanja ovih zajednica, povezanih $s$ analizom Ellenbergovih indeksa temperature, svjetlosti, reakcije tla itd. Prema Lakušiću i dr., I99I. ova vrsta ekosistema u Bosni i Hercegovini bila je zadovoljavajuća. Međutim, današnji nalaz pokazuje ozbiljne promjene. Gubitak staništa tresetišta zabilježen je u čitavom području istraživanja. Glavni identificirani pokretači su krčenje šuma, promjena staništa $i$ isušivanje vodotoka. Da bi se zaštitila ova vrsta ekosistema i važnih indikatorskih vrsta potrebno je provoditi različite aktivnosti očuvanja i restauracije. 